\title{
Pentachlorophenol (PCP) adsorption from aqueous solution by activated carbons prepared from corn wastes
}

\author{
N. T. Abdel-Ghani - G. A. El-Chaghaby • \\ E. M. Zahran
}

Received: 19 June 2013/Revised: 30 September 2013/Accepted: 17 November 2013/Published online: 17 December 2013

(C) Islamic Azad University (IAU) 2013

\begin{abstract}
Corn wastes generated from starch and glucose production industry were used for the preparation of activated carbons. The prepared activated carbons and a commercial activated carbon were evaluated for their capability of adsorbing pentachlorophenol (PCP) from aqueous solution. Batch adsorption experiments were performed under different operating conditions including $\mathrm{pH}$ (2-8), adsorbent dosage (0.5-4.0 g/l), initial PCP concentration $(10-100 \mathrm{mg} / \mathrm{l})$, contact time (30-300 $\mathrm{min})$, and temperature $\left(25-45^{\circ} \mathrm{C}\right)$. The kinetics and equilibrium models describing the adsorption of PCP by the prepared adsorbents were obtained. The adsorption of PCP by corn waste-based adsorbents was found to follow the secondorder kinetics and the Freundlich equilibrium models. The intraparticle diffusion mechanism was successfully fitted to the obtained experimental data. Thermodynamic studies indicated that the adsorption process was exothermic. The adsorbents surface characterization revealed the presence of many functional groups capable of binding the adsorbate molecules. The study results suggest the possible use of corn wastes as a starting material for the production of activated carbon, thus lowering the costs of wastewater treatment processes.
\end{abstract}

\footnotetext{
N. T. Abdel-Ghani

Chemistry Department, Faculty of Science, Cairo University, Giza, Egypt

G. A. El-Chaghaby $(\square)$

RCFF, Agricultural Research Center, Giza, Egypt

e-mail: ghadiraly@yahoo.com

E. M. Zahran

Holding Company for Water and Wastewater, Greater Cairo

Water Company, Cairo, Egypt
}

Keywords Activated carbon - Adsorption - Corn waste . Isotherms · Kinetics · Pentachlorophenol ·

Thermodynamics

\section{Introduction}

Pentachlorophenol (PCP) is one of the seven chlorophenols with industrial production (Estevinho et al. 2006). Although PCP does not belong to the primarily elaborated list of 12 persistent organic pollutants (POPs), it is considered a persistent compound in the environment (Brás et al. 2005). The United States Environmental Protection Agency (US-EPA) fixed $1 \mu \mathrm{g} / \mathrm{l}$ as the maximum limit of PCP in drinking water, while the European Union limited the maximum PCP discharge concentration in industrial effluents to $1-2 \mathrm{mg} / \mathrm{l}$ (Estevinho et al. 2006).

Aqueous effluents from industrial operations such as polymeric resin production, oil refining, iron-steel, petroleum, pesticide, paint, solvent, pharmaceutics, wood-preserving chemicals, coke-oven, and paper and pulp industries contain chlorophenolic compounds (Jianlong et al. 2000). PCP has been widely used as biocide mainly in wood preservation industries and other pesticide applications (Mathialagan and Viraraghavan 2009).

Pentachlorophenol is acutely toxic to a variety of microorganisms and mammals; as it is an inhibitor of oxidative phosphorylation, it appears to accumulate within the food chain and is thought to be mutagenic or at least comutagenic (Mollah and Robinson 1996). PCP acts by uncoupling oxidative phosphorylation via making cell membranes permeable to protons, resulting in dissipation of transmembrane proton gradients and consequential electrical potentials (Law et al. 2003). 
It is thus necessary to remove PCP from contaminated water, and several methods have been used for this purpose. These methods include oxidation, biological degradation, membrane filtration, ion exchange, reverse osmosis, photocatalytical degradation, and adsorption (Domínguez-Vargas et al. 2009). The water treatment costs of these technologies range from 10 to 450 US\$ per cubic meter of treated water, except adsorption technology. The cost of water treatment using adsorption is 5.0-200 US\$ per cubic meter of water (Gupta et al. 2012). Moreover, ability of adsorption to remove toxic chemicals without disturbing the quality of water or leaving behind any toxic degraded products has augmented its usage in comparison with some other treatment methods (Mittal 2006). Thus, among various water purification and recycling technologies, adsorption is a fast, inexpensive, and universal method (Ali and Gupta 2007).

Adsorption as a cost-effective technique has been widely applied for the removal of PCP from aqueous solutions. Various adsorbents were successfully used for PCP removal, e.g., peat-bentonite mixture (Viraraghavan and Slough 1999), activated sludge biomass (Jianlong et al. 2000), spent mushroom compost (Law et al. 2003), pine bark (Brás et al. 2005), almond shell residues (Estevinho et al. 2006), coal fly ash (Estevinho et al. 2007), and fungal biomass (Mathialagan and Viraraghavan 2009).

According to Gupta et al. (2009), activated carbon is considered as an effective adsorbent but the high cost of activated carbon has stimulated interest in examining the feasibility of using cheaper waste materials as potential adsorbents. Recently, activated carbons prepared from natural materials have captured the interest of many researchers for their high adsorption capacities and low cost compared to commercial activated carbons (CAC). In the adsorption technique, the major concern is the selection of adsorbent material (Mittal et al. 2009). In this respect, the production of activated carbon from agricultural by-products has potential economic and environmental impacts as it converts unwanted, low-value agricultural waste to a useful high-value adsorbent (Ekpete and Harcourt 2011).

Generally, two types of activation methods are employed in the production of activated carbon, namely physical and chemical activation (Olorundare et al. 2012). However, chemical activation is now widely applied for the activation because of its lower activation temperature and higher product yield compared with the physical one (Tongpoothorn et al. 2011). According to Tongpoothorn et al. (2011), it was found that alkaline hydroxides such as $\mathrm{KOH}$ and $\mathrm{NaOH}$ can be used to prepare activated carbons with high specific surface area. Although $\mathrm{NaOH}$ and $\mathrm{KOH}$ are related compounds, the reaction mechanisms of these two hydroxides are known to be different. $\mathrm{KOH}$ intercalates between carbon layers while $\mathrm{NaOH}$ reacts with the most energetic sites of the surface, thus presenting a reactivity that strongly depends on both rank and crystallinity of the carbonaceous precursor (Perrin et al. 2004), and sodium hydroxide activation was shown to be particularly interesting because of its low cost, simple handling, and low corroding action (Perrin et al. 2004).

The aims of this work were to utilize corn wastes for the preparation of activated carbons and to investigate the potential use of the prepared carbons for PCP adsorption from aqueous solution at different optimizing conditions. The present research was carried out during 2012-2013 in the laboratories of the Holding Company for water and Wastewater, Greater Cairo Water Company, Cairo, Egypt.

\section{Materials and methods}

\section{Pentachlorophenol (PCP)}

Pentachlorophenol used as an adsorbate in this study was supplied by Supelco Park, Bellefonte, chemical reagents Co. (USA), and was used without any further purification. The molecular weight of PCP is $197.45 \mathrm{~g} / \mathrm{mol}$ and it has a chemical formula of $\mathrm{C}_{6} \mathrm{H}_{3} \mathrm{Cl}_{3} \mathrm{O}$. Corn cobs and corn nodes were obtained from the Egyptian Starch \& Glucose Manufacturing Company (ESGC); the company generates corn waste of 247.042 tone/year. The CAC used in the present study is coconut shell-based activated carbon with the following specifications: ash (3\%), moisture (10\%), and bulk density $\left(0.4 \mathrm{~g} / \mathrm{cm}^{3}\right)$.

\section{Activated carbon preparation and characterization}

The activated carbons were prepared according to the procedure described by Tongpoothorn et al. (2011) with some modification. The starting materials (either corn nodes or corn cobs) were cleaned with water and dried at $110{ }^{\circ} \mathrm{C}$ for $48 \mathrm{~h}$. The dried samples were crushed with a blender and sieved before they were carbonized at $400{ }^{\circ} \mathrm{C}$ for $1 \mathrm{~h}$ in a muffle furnace in order to produce charcoal. The charcoals obtained were then subjected to impregnation in $\mathrm{NaOH}$ solution by weight ratio ( $1 \mathrm{~g}$ charcoal/4 g $\mathrm{NaOH}$ ) at $70{ }^{\circ} \mathrm{C}$ for $24 \mathrm{~h}$. The resulting samples were further activated in a muffle furnace at $800{ }^{\circ} \mathrm{C}$ for $2 \mathrm{~h}$. After cooling, the activated carbons were washed successively several times with $1 \mathrm{M} \mathrm{HCl}$ followed by hot water until the $\mathrm{pH}$ became neutral $(=7)$. Finally, the washed samples were dried at $110{ }^{\circ} \mathrm{C}$. The obtained activated carbons prepared from corn cobs and corn nodes were abbreviated as CCAC and CNAC, respectively.

The prepared activated carbons were characterized by Fourier transformation infrared technique (FTIR) over the range of $500-4,000 \mathrm{~cm}^{-1}$ using Thermo Nicolet Avatar 370 FTIR Spectrometer, Thermo scientific co. The surface 
characteristics of the adsorbents were also investigated by scanning electron microscope (SEM) using JEOL, JSM6490LA SEM-JEOL USA, Inc.

The $\mathrm{pH}$ point of zero charge $\left(\mathrm{pH}_{\mathrm{pzc}}\right)$ was carried out by taking $50 \mathrm{ml}$ of $0.1 \mathrm{M} \mathrm{NaCl}$ solutions in different closed Erlenmeyer flasks. The $\mathrm{pH}$ of the solution $\left(\mathrm{pH}_{\mathrm{o}}\right)$ in each flask was adjusted to values of $2,4,6,8,10$, and 12 by adding $0.1 \mathrm{M} \mathrm{HCl}$ or $0.1 \mathrm{M} \mathrm{NaOH}$ solutions. Then, $0.2 \mathrm{~g}$ of each of the adsorbents was added and agitated in a shaker for $1 \mathrm{~h}$ and allowed to stay for $48 \mathrm{~h}$ to reach equilibrium with intermittent manual shaking. Then, the final $\mathrm{pH}$ value $\left(\mathrm{pH}_{\mathrm{f}}\right)$ of the supernatant liquid was noted (Abdel Ghani et al. 2013). The value of $\mathrm{pH}_{\mathrm{pzc}}$ is the $\mathrm{pH}$ at which $\mathrm{pH}_{\mathrm{o}}=\mathrm{pH}_{\mathrm{f}}$.

Pentachlorophenol (PCP) adsorption experiments

The effects of operation parameters on the adsorption of PCP onto corn waste-derived activated carbons such as $\mathrm{pH}(2-8)$, adsorbent dosage $(0.5-4.0 \mathrm{~g} / \mathrm{l})$, initial PCP concentration (10-100 mg/l), contact time (30-300 min), and temperature $\left(25-45^{\circ} \mathrm{C}\right)$ were studied in a batch mode of operation. The solution $\mathrm{pH}$ was adjusted with $0.1 \mathrm{~mol} / \mathrm{L} \mathrm{NaOH}$ and $0.1 \mathrm{~mol} /$ $\mathrm{L} \mathrm{HCl}$ solutions. In each batch experiment, a 250-ml stopper conical flask containing $50 \mathrm{ml}$ PCP of certain concentration was mixed with a certain weight of each of the adsorbents and agitated mechanically at the controlled temperature in a shaking water bath at $200 \mathrm{rpm}$ until equilibrium was reached. The mixture was then filtered and the remaining PCP concentration was determined at wavelength $305 \mathrm{~nm}$ using a spectrophotometer Jenway 6715 UV/Vis spectrophotometer, Bibby-Barloworld Scientific Ltd.

The amount of PCP adsorbed at equilibrium (adsorption capacity), $q_{\mathrm{e}}(\mathrm{mg} / \mathrm{g})$ was calculated by the following equation:

$q_{\mathrm{e}}=\left[\frac{c_{\mathrm{i}}-c_{\mathrm{e}}}{w}\right] * v$

whereas the PCP removal percentage (R \%) was calculated by the following equation:

$R \%=\left[\frac{c_{\mathrm{i}}-c_{\mathrm{e}}}{c_{\mathrm{i}}}\right] * 100$

where $C_{\mathrm{i}}$ and $C_{\mathrm{e}}$ are the PCP concentrations at the initial time and at equilibrium (mg/l), respectively. $V$ is the volume of the solution (1) and $W$ is the mass of adsorbent used (g).

\section{Results and discussion}

Determination of equilibrium time

Equilibrium time is one of the most important parameters for selecting a wastewater treatment system (Abdel Ghani and El-Chaghaby 2007). The equilibrium time for the adsorption of PCP onto (CNAC), (CCAC), and (CAC) was determined over a period from 30 to $300 \mathrm{~min}$. The experiments were performed using an adsorbent dose of (2 g/l), initial solution $\mathrm{pH}(6)$, PCP concentration (10-100 mg/l), at room temperature $\left(25 \pm 2{ }^{\circ} \mathrm{C}\right)$, and $200 \mathrm{rpm}$ shaking speed. The results are presented in Fig. 1a-c for CNAC, CCAC, and CAC, respectively. It can be observed that the adsorption of PCP onto the studied adsorbents generally increased by increasing the contact time until equilibrium was reached after 210, 240, and $180 \mathrm{~min}$. for CNAC, $\mathrm{CCAC}$, and $\mathrm{CAC}$, respectively. The difference in the equilibrium time between the studied adsorbents might be due to the differences in the surface properties of the adsorbents (Gupta et al. 2011a). This result is interesting because equilibrium time is one of the important considerations for economical wastewater treatment applications (Mbadcam et al. 2011).

Thus, further experiments were conducted at $270 \mathrm{~min}$ to ensure maximum PCP adsorption by the studied adsorbents. Figure 1 also indicate that the total adsorption capacities increased with increasing the initial PCP concentrations from 10 to $100 \mathrm{mg} / \mathrm{l}$, which may be attributed to the finding that the initial sorbate concentration provides an important driving force to overcome all mass transfer resistance (Cherifi et al. 2009).

pHpzc and effect of solution $\mathrm{pH}$ on PCP adsorption

The solution $\mathrm{pH}$ is largely related to the surface chemistry of the adsorbent and on the chemistry of the adsorbate in solution. The surface chemistry of the three investigated adsorbents (CNAC, CCAC, and CAC) has been studied by determining their point of zero charge $\mathrm{pH}\left(\mathrm{pH}_{\mathrm{pzc}}\right)$. The point of zero charge $\mathrm{pH}$ is the $\mathrm{pH}$ at which the surface charge of the solid phase is zero (Mubarik et al. 2012). Figure 2 shows the final against initial $\mathrm{pH}$ plots for the studied activated carbons. The intersection of each of these plots with the $y=x$ function is considered to be the pHpzc. The pHpzc was found to be around 3, 6, and 7 for the CAC, corn nodes activated carbon, and corn cobs activated carbons, respectively.

The higher $\mathrm{pH}_{\mathrm{pzc}}$ values obtained for CCAC and CNAC as compared to the highly acidic $\mathrm{pH}_{\mathrm{pzc}}$ value of CAC could be attributed to the preparation method of both CCAC and CNAC, which involved an alkali activation step. The acidic or basic pretreatments of the adsorbents caused a change in their surface acidity. According to Kang et al. (2008), acidic pretreatment produces many acidic surface groups, which increased the acidic value. In contrast, basic pretreatment of ACF and GAC decreases the number of acidic groups and increases the number of basic groups on the surface. 
Fig. 1 Effect of contact time on PCP adsorption by a CNAC, b CCAC, and $\mathbf{c}$ CAC, adsorbent dosage $=2 \mathrm{~g} / \mathrm{l}, \mathrm{pH}: 6.0$, shaking speed: $200 \mathrm{rpm}$,

Temp $=25 \pm 2{ }^{\circ} \mathrm{C}$
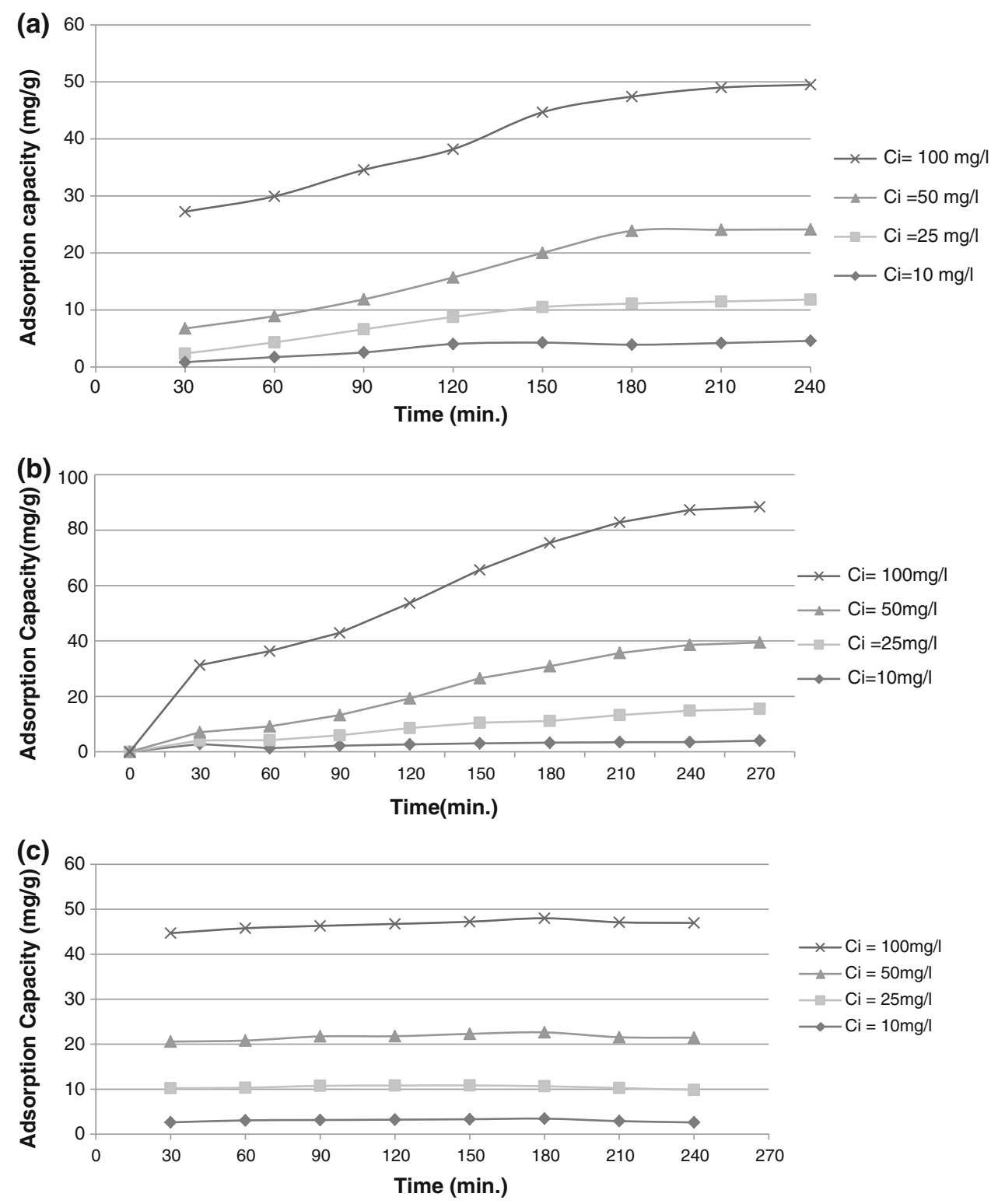

In order to find the optimum $\mathrm{pH}$ for maximum PCP removal onto CNAC, CCAC, and CAC, batch experiments were performed in the $\mathrm{pH}$ range from 2 to 8 using an adsorbent dose of $2 \mathrm{~g} / \mathrm{l}$ and PCP solutions of $25 \mathrm{mg} / \mathrm{l}$ at room temperature. The results are presented graphically in Fig. 3.

The effect of $\mathrm{pH}$ on PCP removal by the three studied adsorbents can be explained as previously mentioned in terms of both the surface chemistry of the adsorbents and the chemistry of PCP in solution. The carbon surface is positively charged at $\mathrm{pH}<\mathrm{pHpzc}$ and negatively charged at $\mathrm{pH}>\mathrm{pHpzc}$ (Liu et al. 2010). It is also important to mention the chemical characteristics of PCP while discussing the effect of solution $\mathrm{pH}$ on biosorption. PCP, the strongest acid of the phenol family, has a pKa value of 4.75 (Schellenberg et al. 1984). Thus, PCP will be mainly in protonated form at $\mathrm{pH}<\mathrm{pKa}$ and in deprotonated form at pH $>$ pKa (Liu et al. 2010).

As can be seen from Fig. 3, the maximum uptake of $\mathrm{PCP}$ by CNAC and CCAC was achieved at $\mathrm{pH}=6$. At this $\mathrm{pH}$ value, the surface of CNAC will be neutral $(\mathrm{pH}=\mathrm{pHpzc})$ and the surface of CCAC will be positively charged ( $\mathrm{pH}<\mathrm{pHpzc}$ ). It has also to be noted that at $\mathrm{pH}=6$, the PCP is mainly in its deprotonated form. Thus, attraction between PCP ions and the adsorbent's surface will take place. According to (Ould-Idriss et al. 2011) at $\mathrm{pH}$ values in the vicinity of neutrality, the adsorbents will tend to adsorb preferably cations, due to the cooperative effect of the net negative surface charge.

At $\mathrm{pH}$ values lower than the adsorbents pHpzc, the removal of PCP by CNAC and CCAC was minimal because of the repulsive forces existing between the 
Fig. 2 The final against initial $\mathrm{pH}$ plots for the studied activated carbons

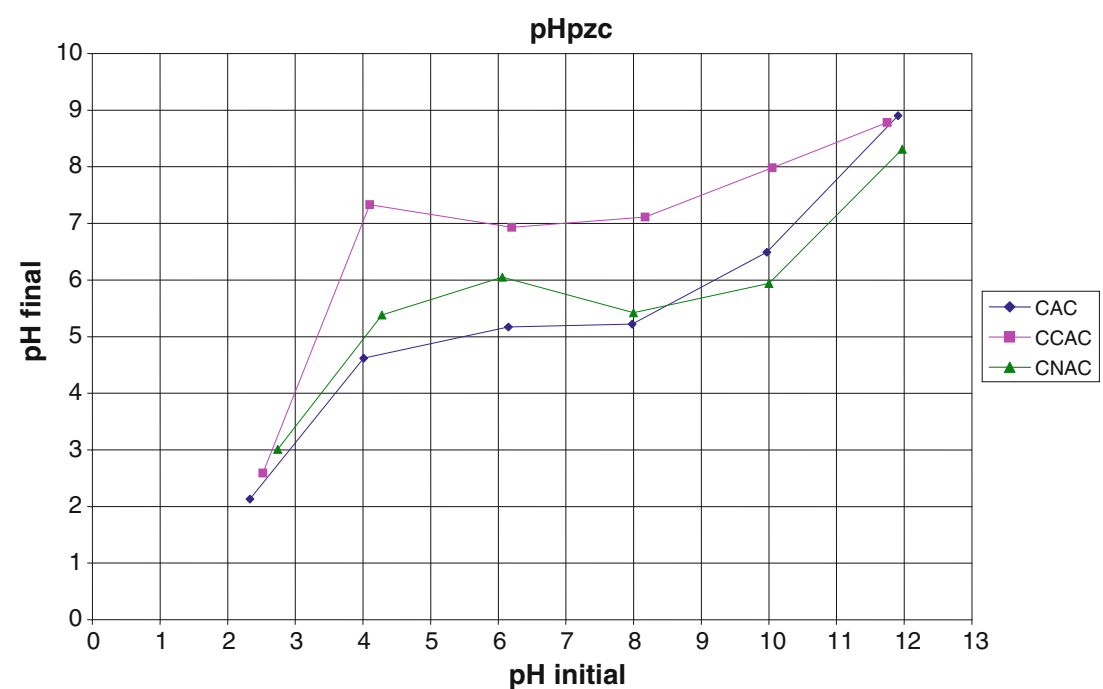

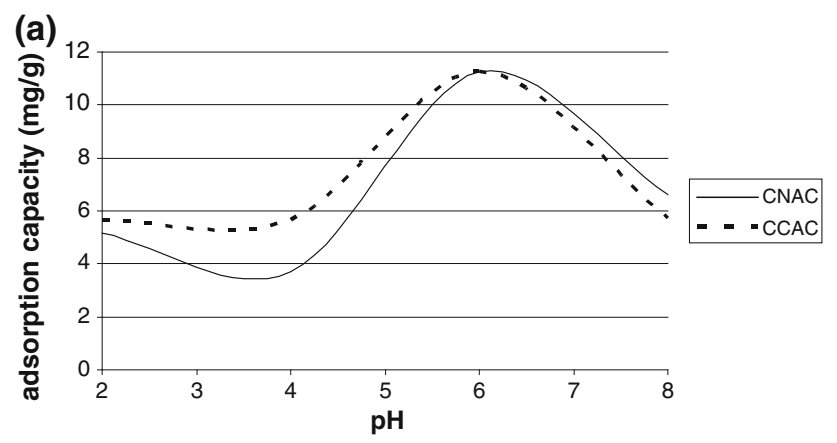

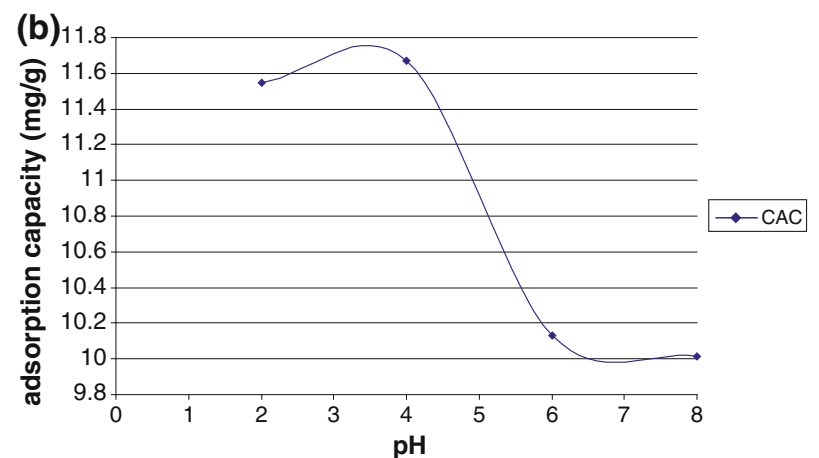

Fig. 3 Effect of $\mathrm{pH}$ on the adsorption of PCP by a CNAC, CCAC, and $\mathbf{b}$ CAC at PCP initial concentration $=25 \mathrm{mg} / \mathrm{l}$, adsorbent dosage $=0.1 \mathrm{~g} / 50 \mathrm{ml}$, contact time $270 \mathrm{~min}$

positively charged activated carbon surface and the PCP present in its protonated form.

The removal of PCP by CNAC and CCAC decreased sharply after $\mathrm{pH}$ 6. This observation was attributed to the fact that at $\mathrm{pH}$ values higher than $\mathrm{pHpzc}$, the adsorbent surface will be negatively charged. At the same time, PCP exists entirely in the anionic form at neutral and basic $\mathrm{pH}$ (Mathialagan and Viraraghavan 2009). Therefore, electrostatic repulsion between the negatively charged adsorbent surface and the anionic PCP will take place leading to lower adsorption.

Regarding the effect of $\mathrm{pH}$ on the removal of PCP by $\mathrm{CAC}$, it can be seen from Fig. 3 that the percentage removal of $\mathrm{PCP}$ was maximum at $\mathrm{pH}=4$ and declined by increasing the $\mathrm{pH}$ above this value with a sharp decrease at $\mathrm{pH}>8$. Similar results were obtained by (Lü et al. 2011) for the adsorption of phenol by lignite activated carbon. According to these authors, at very low $\mathrm{pH}$ values, there are many positive charges on the surface of activated carbon, which gives a large static repulsion force. As $\mathrm{pH}$ increases, the static repulsion force decreases and the phenol adsorption increases. At $\mathrm{pH}>8$, the decrease in phenol adsorption may be resulted from three reasons. First, the negative charges on the surface of activated carbon increases with $\mathrm{pH}$ and phenol changes from molecular state to ionic state, which makes the repulsion force between phenol ions and the activated carbon significant. Second, the phenol ions adsorbed by the activated carbon also have a repulsion force between themselves. Third, the negative charges on the surface of activated carbon are repulsive that represses the disgregation of phenol ions and phenol adsorption.

Kinetic studies

Kinetic studies were conducted at the optimum $\mathrm{pH}$ predetermined for each of the investigated adsorbents using an adsorbent dose of $0.1 \mathrm{~g}$; with $50 \mathrm{ml}$ of PCP solution at different concentrations $(10,25,50$, and $100 \mathrm{mg} / \mathrm{l})$. The pseudo-first-order and pseudo-second-order kinetic models were applied to the experimental data in order to predict the adsorption kinetics.

The pseudo-first-order equation can be written as follows (Lagergren, 1898): $\ln \left(q_{\mathrm{e}}-q_{\mathrm{t}}\right)=\ln q_{\mathrm{e}}-k_{1} t$, where 
$q_{\mathrm{e}}$ and $q_{\mathrm{t}}(\mathrm{mg} / \mathrm{g})$ are the amounts of PCP adsorbed at equilibrium and at time $t$, respectively, $k_{1}\left(\mathrm{~min}^{-1}\right)$ is the pseudo-first-order rate constant. A straight line of $\ln \left(q_{\mathrm{e}}-\right.$ $q_{\mathrm{t}}$ ) versus $\mathrm{t}$ suggests the applicability of this kinetic model, and $q_{\mathrm{e}}$ and $k_{1}$ can be determined from the intercept and slope of the plot, respectively.

The pseudo-second-order model is in the following form: $t / q_{\mathrm{t}}=1 / k_{2} q_{\mathrm{e}}^{2}+t / q_{\mathrm{e}}$, where $k_{2}(\mathrm{~g} / \mathrm{mg} \min )$ is the rate constant of the second-order equation (Ho and McKay 1998). The plot of $t / q_{\mathrm{t}}$ versus $t$ should give a straight line if pseudo-second-order kinetic model is applicable and $q_{\mathrm{e}}$ and $k_{2}$ can be determined from slope and intercept of the plot, respectively.

The constants calculated from the models are given in Table 1. As seen from Table 1, the determination coefficient $\left(R^{2}\right)$ values of the pseudo-second-order kinetic model were higher than their corresponding $\left(R^{2}\right)$ values of the pseudo-first-order kinetic model for the three studied adsorbents. Comparing the $q_{\mathrm{e}}$ values calculated from the kinetic models with the experimental $q_{\mathrm{e}}$ values, it can be noted that the $q_{\mathrm{e}}$ values calculated from the pseudo-secondorder model are in good agreement with the experimental ones in contrary to those calculated from the pseudo-firstorder model.

The obtained results thus are suggesting that the adsorption of PCP onto CNAC, CCAC, and CAC follows the pseudo-second-order kinetic model. These results indicate that the rate-limiting step for the adsorption of PCP onto the three studied carbons may be chemisorption (El-Naas et al. 2010). According to El-Naas et al. (2010), this may indicate that the adsorption takes place via surface exchange reactions until the surface functional sites are fully occupied; thereafter, phenol molecules diffuse into the activated carbon network for further interactions (such as inclusion complex, hydrogen bonding, and hydrogen phobic interactions (Bulut et al. 2008).

\section{Adsorption mechanism study}

It has been previously reported that usually intraparticle diffusion is the rate-limiting step in the adsorption of phenols from water on activated carbons (Lorenc-Grabowska et al. 2012).

The intraparticle diffusion equation, suggested by Weber and Morris (1963), can be expressed as follows: $q_{\mathrm{t}}=K_{\mathrm{t}}^{0.5}+C_{\mathrm{b}}$.

Where $q_{\mathrm{t}}$ is the adsorbed quantity of PCP, $K$ is the intraparticle diffusion parameter, and $C_{\mathrm{b}}$ is the thickness of the boundary layer.

The plot of $q_{\mathrm{t}}$ versus $t^{0.5}$ would give a straight line, when the adsorption (or sorption) process is controlled by intraparticle diffusion only, and if it exhibits multilinear plots, then there are two or more steps affecting the

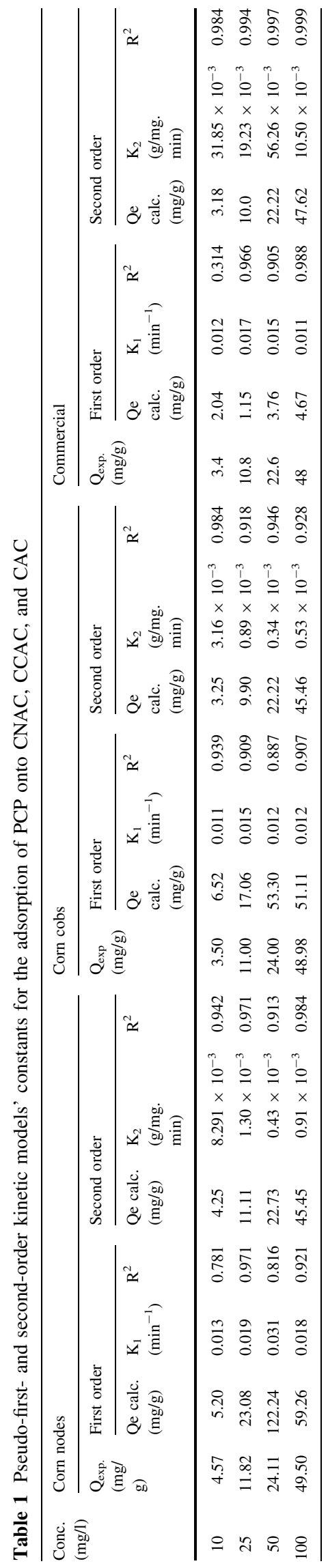


adsorption process (Abdel Salam 2012). The experimental data for each of the three studied adsorbents show two distinct linear parts indicating that two steps are involved in the adsorption process. The first step is attributed to diffusion through the solution toward the external surface of the adsorbent or the boundary layer diffusion of solute molecules, whereas the second step corresponds to the gradual adsorption stage, where intraparticle diffusion is the rate-limiting step (Lorenc-Grabowska et al. 2012).

The values of the different parameters calculated from the plots of $\mathrm{q}_{\mathrm{t}}$ versus $\mathrm{t}^{0.5}$ for the intraparticle diffusion model are summarized in Table 2.

\section{Adsorption equilibrium study}

The analysis of the adsorption data is important for developing an equation that accurately represents the results and that could be used for design purposes (Gupta et al. 2010). Many equilibrium models have been used to describe adsorption process. In the present work, three of the most widely used equilibrium models such as Langmuir [Eq. (1)], Freundlich [Eq. (2)] and Temkin [Eq. (3)] were applied to fit the experimental data.

$q_{\mathrm{e}}=q_{\mathrm{max}} b C_{\mathrm{e}} /\left(1+b C_{\mathrm{e}}\right)$

$q_{\mathrm{e}}=K_{\mathrm{F}} C_{\mathrm{e}}^{1 / \mathrm{n}}$

$q_{\mathrm{e}}=a_{\mathrm{t}}+b_{\mathrm{t}} \ln C_{\mathrm{e}}$

In these equations, $q_{\mathrm{e}}$ and $C_{\mathrm{e}}$ represent the adsorbent capacity at equilibrium ( $\mathrm{mg} / \mathrm{g})$ and the concentration of PCP at equilibrium (mg/l). In the Langmuir equation, $q_{\max }$ is considered the maximum sorption capacity related to the total cover of the surface and $b$ is associated with sorption energy. From the Freundlich model, $K_{\mathrm{F}}$ represents the sorption capacity and $1 / n$ is related to the energy distribution of the sorption sites. The Temkin model constants $a_{\mathrm{t}}$ and $b_{\mathrm{t}}$ are related to the maximum binding energy and heat of adsorption.

The values corresponding to the Langmuir, Freundlich, and Temkin equation parameters are presented in Table 3. Comparing the $R^{2}$ values of the three models, it can be noticed that the Freundlich equation showed the best fit to the experimental data for the three studied adsorbents with $\left(R^{2}>0.99\right)$. It can be also seen that the value of constant $(n)$ is greater than unity indicating a favorable adsorption for the three studied activated carbons (Prakash Kumar et al. 2005).

In the present study, the maximum adsorption capacities $\left(q_{\mathrm{m}}\right)$ obtained from the Langmuir model for PCP removal onto CNAC, CCAC, and CAC were found to be 7.143, 5.260 , and $9.090 \mathrm{mg} / \mathrm{g}$, respectively. The maximum adsorption capacities for PCP removal onto various adsorbents as previously reported in the literature could be 
Table 3 Adsorption isotherms' calculated parameters for the adsorption of PCP onto CNAC, CCAC, and CAC

\begin{tabular}{lllccl}
\hline Model & Equation & Parameters & \multicolumn{3}{l}{ Adsorbent } \\
\cline { 3 - 6 } & & & CNAC & CCAC & CAC \\
\hline Langmuir & $q_{\mathrm{e}}=q_{\max } b C_{\mathrm{e}} /$ & $\begin{array}{c}q_{\max }(\mathrm{mg} / \\
\mathrm{g})\end{array}$ & 7.143 & 5.260 & 9.090 \\
& $\left(1+b C_{\mathrm{e}}\right)$ & $b(1 / \mathrm{mg})$ & 0.667 & 0.323 & 0.105 \\
& & $R^{2}$ & 0.985 & 0.964 & 0.904 \\
Freundlich & $\mathrm{q}_{e}=\mathrm{K}_{\mathrm{F}} \mathrm{C}_{\mathrm{e}}^{1 / \mathrm{n}}$ & $K_{\mathrm{f}}$ & 16.07 & 1.245 & 3.56 \\
& & $n$ & 2.251 & 3.504 & 1.357 \\
& & $R^{2}$ & 0.990 & 0.995 & 0.995 \\
\multirow{5}{*}{ Temkin } & $\mathrm{q}_{\mathrm{e}}=\mathrm{a}_{\mathrm{t}}+\mathrm{b}_{\mathrm{t}}$ & $a_{\mathrm{t}}$ & 16.99 & 25.62 & 0.251 \\
& $\operatorname{lnC}_{\mathrm{e}}$ & $b_{\mathrm{t}}$ & 24.16 & 64.51 & 0.029 \\
& & $R^{2}$ & 0.819 & 0.866 & 0.758 \\
\hline
\end{tabular}

summarized as follows: $15.5 \mathrm{mg} / \mathrm{g}$ for spent mushroom compost (Law et al. 2003), $1.7 \mathrm{mg} / \mathrm{g}$ for pine bark (Brás et al. 2005), $2.5 \mathrm{mg} / \mathrm{g}$ for coal fly ash (Estevinho et al. 2007), 12.9 and $8.18 \mathrm{mg} / \mathrm{g}$ for activated charcoal and multiwall carbon nanotubes, respectively (Abdel Salam and Burk 2009).

Effect of temperature and adsorption thermodynamics

The experimental results obtained from PCP adsorption by CNAC, CCAC, and CAC at different temperatures $(25,35$, and $45{ }^{\circ} \mathrm{C}$ showed that the removal percentage of PCP decreased with an increase in temperature, implying an exothermic nature of the adsorption process (El-Naas et al. 2010). According to Senturk et al. (2009), the decrease in adsorption with the rise in temperature may be due to the weakening of adsorptive forces between the active sites of the adsorbent and adsorbate species and also between the vicinal molecules of the adsorbed phase.

In order to gain an insight about the feasibility of the adsorption process, the thermodynamic parameters
Table 4 Thermodynamic parameters for the adsorption of PCP onto CNAC, CCAC, and CAC

\begin{tabular}{llrll}
\hline & & \multicolumn{1}{l}{ CNAC } & \multicolumn{1}{l}{ CCAC } & \multicolumn{1}{l}{ CAC } \\
\hline$\Delta \mathrm{G}(\mathrm{J} / \mathrm{mol})$ & $\left(25^{\circ} \mathrm{C}\right)$ & $-9,778.625$ & $-8,496.331$ & $-7,312.008$ \\
& $\left(35^{\circ} \mathrm{C}\right)$ & $-8,054.104$ & $-6,935.52$ & $-8,953.996$ \\
& $\left(45^{\circ} \mathrm{C}\right)$ & $-4,596.857$ & $-3,628.754$ & $-4,749.212$ \\
$\Delta \mathrm{H}(\mathrm{KJ} / \mathrm{mol})$ & & -84.821 & -78.981 & -43.557 \\
$\Delta \mathrm{S}(\mathrm{J} \mathrm{mol} / \mathrm{K})$ & & -251.584 & -236.211 & -119.163 \\
\hline
\end{tabular}

including free energy change $\left(\Delta G^{\circ}\right)$, enthalpy $\left(\Delta H^{\circ}\right)$, and entropy $\left(\Delta S^{\circ}\right)$ were calculated based on equations (IV-VI). In these equations, $\mathrm{R}$ is the universal gas constant $(8.314 \mathrm{~J} \mathrm{~mol} / \mathrm{K})$ and $\mathrm{T}$ is the temperature $(\mathrm{K}) . \mathrm{K}_{\mathrm{d}}$ is the distribution coefficient $\left(K_{\mathrm{d}}=q_{\mathrm{e}} / C_{\mathrm{e}}\right)$ where $q_{\mathrm{e}}$ and $C_{\mathrm{e}}$ are the equilibrium concentration of PCP on adsorbent $(\mathrm{mg} / \mathrm{g})$ and in the solution $(\mathrm{mg} / \mathrm{l})$, respectively.

$\Delta G^{\circ}=-R T \ln K_{\mathrm{d}}$

$\Delta G^{\circ}=\Delta H^{\circ}-T \Delta S^{\circ}$

$\ln K_{\mathrm{d}}=\left(\Delta S^{\circ} / R\right)-\Delta H^{\circ} / R T$

The values of $\Delta H^{\circ}$ and $\Delta S^{\circ}$ were obtained from the slope and intercept of the plot between $\ln K_{\mathrm{d}}$ versus $1 / T$, respectively (Fig. 4). The values of the thermodynamic parameters evaluated in the present study are presented in Table 4. Negative $\Delta G^{\circ}$ values were obtained for the adsorption of $\mathrm{PCP}$ on the three studied adsorbents indicating spontaneous nature of the adsorption (Ahmed and Theydan 2012) and the feasibility of the process (Mittal et al. 2008, 2010).

In accordance with the experimental results, negative values were obtained for the enthalpy of adsorption $\Delta H^{\circ}$, which gives a further confirmation on the exothermic nature of the adsorption process. The negative $\Delta S^{\circ}$ values suggest according to (Ahmed and Theydan 2012) a decrease in the randomness at sorbate/solution interface during the adsorption process.
Fig. 4 Plots of $1 / \mathrm{T}$ versus $\ln K_{d}$ for the adsorption of PCP by CNAC, CCAC, and CAC

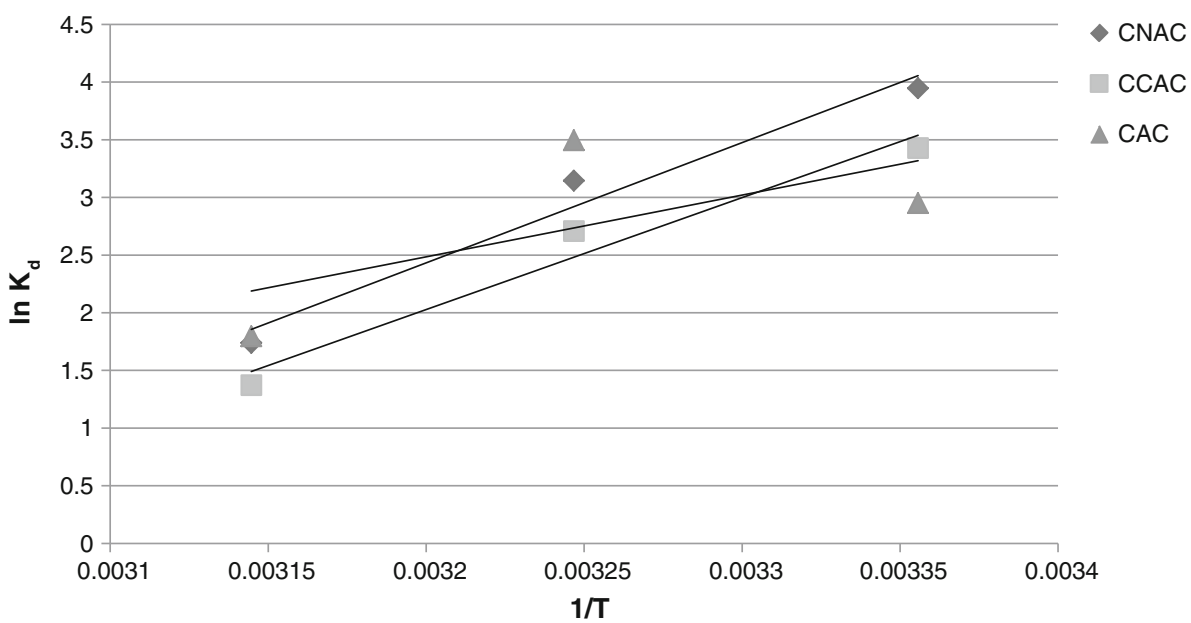




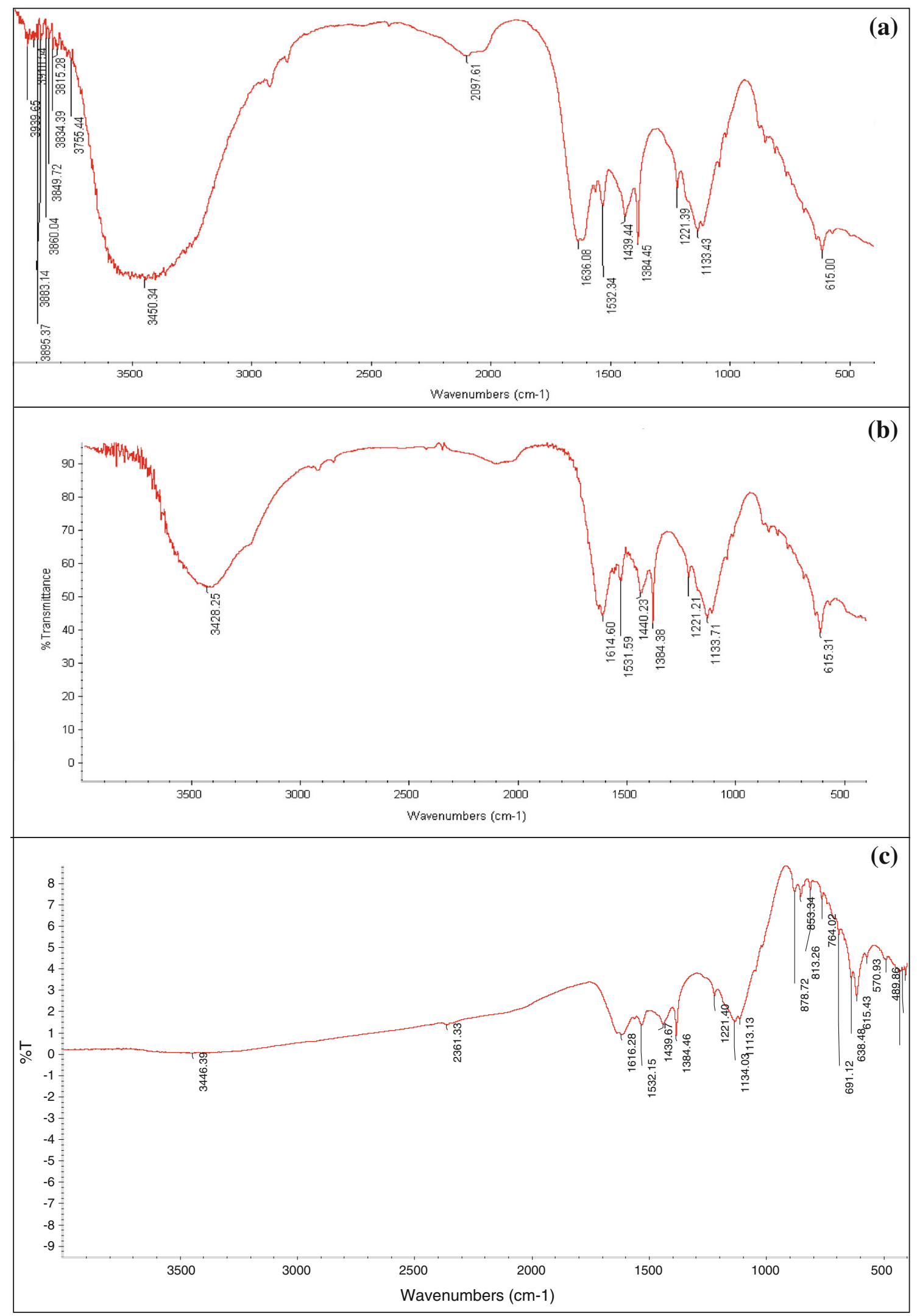

Fig. 5 FTIR spectrum of y a CNAC, b CCAC, and $\mathbf{c}$ CAC 
Fig. 6 SEM micrographs of a CNAC, b CCAC, and $\mathbf{c} \mathrm{CAC}$
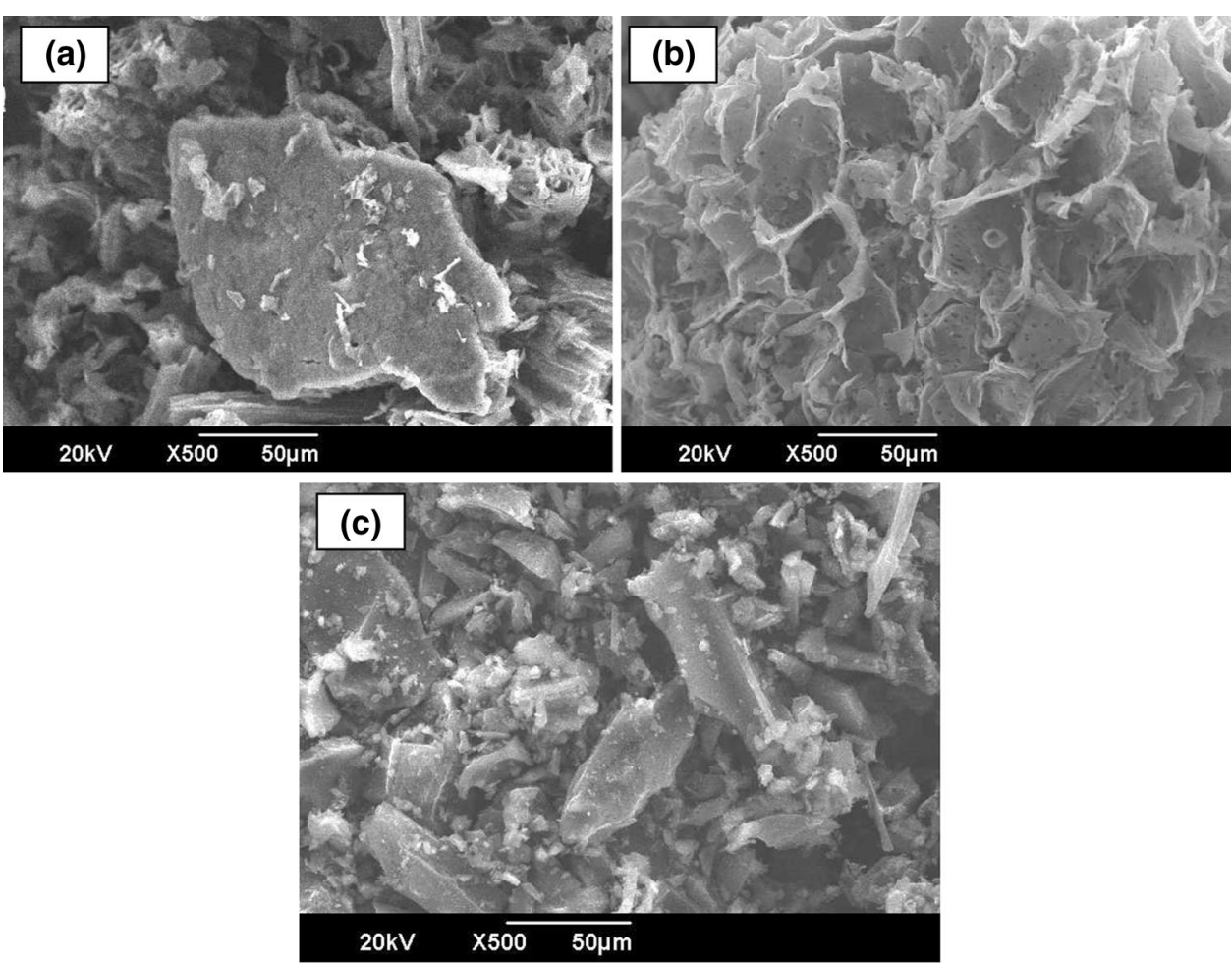

Adsorbents characterization

The FTIR spectra of the activated carbons prepared from corn nodes and corn cobs as well as CAC are shown in Fig. 5. It can be observed that the spectra of the activated carbons prepared from corn wastes are quite similar, whereas these spectrum varied by some deviations when compared to the CAC spectrum.

The spectrum of CNAC (Fig. 5a) depicts a strong peak at $3,450.34 \mathrm{~cm}^{-1}$ and a similar band but with smaller intensity was observed in the CCAC spectrum (Fig. 5b) at $3,428.25 \mathrm{~cm}^{-1}$ these bands are characteristic of the stretching vibration of hydrogen bonded to the hydroxyl group (from alcohol, phenol, or carboxyl) and water adsorbed by the activated carbon (Olorundare et al. 2012) or adsorption of some atmospheric water during FTIR measurements (Gupta et al. 2011b). On the other hand, the spectrum of CAC (Fig. 5c) displayed very weak and broad band at 3,446.39, which is due to either moisture, $\mathrm{O}-\mathrm{H}$, or carboxylic groups. Another band was observed at $2,361.33 \mathrm{~cm}^{-1}$, which may be attributed to $\mathrm{C}-\mathrm{H}$ interaction with the surface of the carbon. The bands around 1,384 and $1,440 \mathrm{~cm}^{-1}$ displayed in all spectra are assigned to $\mathrm{C}-\mathrm{H}$ vibration for $-\mathrm{CH}_{3}-$ and $-\mathrm{CH}_{2}=($ El-Hendawy 2009). The FTIR bands in the region between 1,430 and $1,660 \mathrm{~cm}^{-1}$ are generally ascribed to the skeletal $\mathrm{C}=\mathrm{C}$ vibrations in the aromatic rings (El-Hendawy 2009). The band around $1,220 \mathrm{~cm}^{-1}$ in Fig. 5 was assigned to $\mathrm{C}-\mathrm{O}-\mathrm{C}$ asymmetrical axial deformation of ethers or $\mathrm{C}-\mathrm{C}(=\mathrm{O})-\mathrm{C}$ axial and angular deformation of ketones (Vargas et al. 2011). The FTIR analysis of the adsorbents revealed the presence of many functional groups such as hydroxyl groups, carbonyl group, ethers, and aromatic compounds capable of binding the adsorbate molecules present in solution.

Figure 6 displays the SEM micrographs of CNAC, CCAC, and CAC. The surface morphology of corn nodes activated carbon (Fig. 6a) reveals a cracked surface with irregular holes. The SEM micrograph of corn cobs activated carbon (Fig. 6b) shows a rough texture with heterogeneous surface and a variety of randomly distributed pore size. The CAC (Fig. 6c) has a rough and heterogeneous surface with some cracks. The texture of the studied adsorbents as observed from their SEM micrographs indicates relatively high surface area (Tongpoothorn et al. 2011).

\section{Conclusion}

Activated carbons prepared from corn wastes have been successfully used as adsorbents for the removal of PCP from aqueous solution. The adsorption of PCP onto the studied adsorbents reached its equilibrium in a short time (180-240 min.). The adsorption was found to follow the pseudo-second-order kinetic model with intraparticle diffusion as the rate-limiting step. The Freundlich equilibrium 
model showed the best fit to the experimental data. The maximum adsorption capacities calculated from the Langmuir equation were found to be 7.143 and 5.260 for the activated carbons prepared from corn nodes and corn cobs, respectively. Compared to CAC, the cost of the suggested corn waste-based activated carbons is extremely low and their use for wastewater treatment is suggested to be better from economical and environmental points of view.

Acknowledgments The experimental work of this study was carried out in the Laboratories of Holding Company for water and Wastewater, Greater Cairo Water Company, Cairo, Egypt. So, the authors thank the authorities.

\section{References}

Abdel Ghani NT, El-Chaghaby GA (2007) Influence of operating conditions on the removal of $\mathrm{Cu}, \mathrm{Zn}, \mathrm{Cd}$ and $\mathrm{Pb}$ ions from wastewater by adsorption. Int J Environ Sci Tech 4(4):451-456

Abdel Ghani NT, El-Chaghaby GA, Helal FS (2013) Simultaneous removal of aluminum, iron, copper, zinc, and lead from aqueous solution using raw and chemically treated African beech wood sawdust. Desalination Water Treat 51:3558-3575. doi:10.1080/ 19443994.2012 .750806

Abdel Salam M (2012) Effect of oxidation treatment of multi-walled carbon nanotubes on the adsorption of pentachlorophenol from aqueous solution: kinetics study. Arab J Chem 5:291-296. doi:10.1016/j.arabjc.2010.08.021

Abdel Salam M, Burk RC (2009) Thermodynamics and kinetics studies of pentachlorophenol adsorption from aqueous solutions by multi-walled carbon nanotubes. Water Air Soil Pollut 210:101-111. doi:10.1007/s11270-009-0227-1

Ahmed MJ, Theydan SK (2012) Equilibrium isotherms, kinetics and thermodynamics studies of phenolic compounds adsorption on palm-tree fruit stones. Ecotoxicol Environ Saf 84:39-45. doi:10. 1016/j.ecoenv.2012.06.019

Ali I, Gupta VK (2007) Advances in water treatment by adsorption technology. Nat Protoc 1:2661-2667. doi:10.1038/nprot.2006. 370

Brás I, Lemos L, Alves A, Pereira MFR (2005) Sorption of pentachlorophenol on pine bark. Chemosphere 60:1095-1102. doi:10.1016/j.chemosphere.2004.12.064

Bulut E, Ozacar M, Sengil IA (2008) Equilibrium and kinetic data and process design for adsorption of Congo Red onto bentonite. J Hazard Mater 154:613-622. doi:10.1016/j.jhazmat.2007.10. 071

Cherifi H, Hanini S, Bentahar F (2009) Adsorption of phenol from wastewater using vegetal cords as a new adsorbent. Desalination 244:177-187. doi:10.1016/j.desal.2008.0

Domínguez-Vargas JR, Navarro-Rodríguez JA, de Beltrán Heredia J, Cuerda-Correa EM (2009) Removal of chlorophenols in aqueous solution by carbon black low-cost adsorbents: equilibrium study and influence of operation conditions. J Hazard Mater 169:302-308. doi:10.1016/j.jhazmat.2009.03.075

Ekpete OA, Harcourt P (2011) Preparation and characterization of activated carbon derived from fluted pumpkin stem waste (Telfairia occidentalis Hook F). Res J Chem Sci 1(3):10-17

El-Hendawy AA (2009) An insight into the $\mathrm{KOH}$ activation mechanism through the production of microporous activated carbon for the removal of $\mathrm{Pb} 2+$ cations. Appl Surf Sci 255:3723-3730. doi:10.1016/j.apsusc.2008.10.034
El-Naas MH, Al-Zuhair S, Alhaija MA (2010) Removal of phenol from petroleum refinery wastewater through adsorption on datepit activated carbon. Chem Eng J 162:997-1005. doi:10.1016/j. cej.2010.07.007

Estevinho BN, Ratola N, Alves A, Santos L (2006) Pentachlorophenol removal from aqueous matrices by sorption with almond shell residues. J Hazard Materials 137:1175-1181. doi:10.1016/j. jhazmat.2006.04.001

Estevinho BN, Martins I, Ratola N et al (2007) Removal of 2,4dichlorophenol and pentachlorophenol from waters by sorption using coal fly ash from a Portuguese thermal power plant. J Hazard Mater 143:535-540. doi:10.1016/j.jhazmat.2006.09.072

Gupta VK, Mittal A, Malviya A et al (2009) Adsorption of carmoisine A from wastewater using waste materials-bottom ash and deoiled soya. J Colloid Interface Sci 335:24-33. doi:10.1016/j. jcis.2009.03.056

Gupta VK, Rastogi A, Nayak A (2010) Biosorption of nickel onto treated alga (Oedogonium hatei): application of isotherm and kinetic models. J Colloid Interface Sci 342:533-539. doi:10. 1016/j.jcis.2009.10.074

Gupta VK, Agarwal S, Saleh TA (2011a) Chromium removal by combining the magnetic properties of iron oxide with adsorption properties of carbon nanotubes. Water Res 45:2207-2212. doi:10.1016/j.watres.2011.01.012

Gupta VK, Gupta B, Rastogi A et al (2011b) A comparative investigation on adsorption performances of mesoporous activated carbon prepared from waste rubber tire and activated carbon for a hazardous azo dye-Acid Blue 113. J Hazard Mater 186:891-901. doi:10.1016/j.jhazmat.2010.11.091

Gupta VK, Ali I, Saleh TA et al (2012) Chemical treatment technologies for waste-water recycling-an overview. RSC Adv 2:6380-6388. doi:10.1039/C2RA20340E

Ho YS, McKay G (1998) Kineticmodels for the sorption of dye from aqueous solution wood. J Environ Sci Health Part B Process Saf Environ Prot 76:183-191

Jianlong W, Yi Q, Horan N, Stentiford E (2000) Bioadsorption of pentachlorophenol (PCP) from aqueous solution by activated sludge biomass. Bioresour Technol 75:157-161. doi:10.1016/ S0960-8524(00)00041-9

Kang KC, Kim SS, Choi JW, Kwon SH (2008) Sorption of $\mathrm{Cu}^{2+}$ and $\mathrm{Cd}^{2+}$ onto acid- and base-pretreated granular activated carbon and activated carbon fiber samples. J Ind Eng Chem 14:131-135. doi:10.1016/j.jiec.2007.08.007

Lagergren S (1898) About the theory of so called adsorption of soluble substance, Kung Sven, Veten. Hand 24:1-39

Law WM, Lau WN, Lo KL et al (2003) Removal of biocide pentachlorophenol in water system by the spent mushroom compost of Pleurotus pulmonarius. Chemosphere 52:1531-1537. doi:10.1016/S0045-6535(03)00492-2

Liu Q-S, Zheng T, Wang P et al (2010) Adsorption isotherm, kinetic and mechanism studies of some substituted phenols on activated carbon fibers. Chem Eng J 157:348-356. doi:10.1016/j.cej.2009. 11.013

Lorenc-Grabowska E, Gryglewicz G, Diez MA (2012) Kinetics and equilibrium study of phenol adsorption on nitrogen-enriched activated carbons. Fuel. doi:10.1016/j.fuel.2012.11.056

Lü G, Hao J, Liu L et al (2011) The adsorption of phenol by lignite activated carbon. Chin J Chem Eng 19:380-385. doi:10.1016/ S1004-9541(09)60224-X

Mathialagan T, Viraraghavan T (2009) Biosorption of pentachlorophenol from aqueous solutions by a fungal biomass. Bioresour Technol 100:549-558. doi:10.1016/j.biortech.2008.06.054

Mbadcam JK, Anagho SG, Nsami JN et al (2011) Kinetic and equilibrium studies of the adsorption of lead (II) ions from aqueous solution onto two Cameroon clays: kaolinite and smectite. J Environ Chem Ecotoxicol 3:290-297 
Mittal A (2006) Adsorption kinetics of removal of a toxic dye, Malachite Green, from wastewater by using hen feathers. 133:196-202. doi: 10.1016/j.jhazmat.2005.10.017

Mittal A, Gupta VK, Malviya A, Mittal J (2008) Process development for the batch and bulk removal and recovery of a hazardous, water-soluble azo dye (Metanil Yellow) by adsorption over waste materials (Bottom Ash and De-Oiled Soya). J Hazard Mater 151:821-832. doi:10.1016/j.jhazmat.2007.06.059

Mittal A, Mittal J, Malviya A, Gupta VK (2009) Adsorptive removal of hazardous anionic dye "Congo red" from wastewater using waste materials and recovery by desorption. J Colloid Interface Sci 340:16-26. doi:10.1016/j.jcis.2009.08.019

Mittal A, Mittal J, Malviya A et al (2010) Adsorption of hazardous dye crystal violet from wastewater by waste materials. J Colloid Interface Sci 343:463-473. doi:10.1016/j.jcis.2009.11.060

Mollah AH, Robinson CW (1996) Pentachlorophenol adsorption and desorption characteristics of granular activated carbon-I Isotherms. Water Res 30:2901-2906. doi:10.1016/S00431354(96)00131-5

Mubarik S, Saeed A, Mehmood Z, Iqbal M (2012) Phenol adsorption by charred sawdust of sheesham (Indian rosewood; Dalbergia sissoo) from single, binary and ternary contaminated solutions. J Taiwan Inst Chem Eng 43:926-933. doi:10.1016/j.jtice.2012. 07.003

Olorundare OF, Krause RWM, Okonkwo JO, Mamba BB (2012) Potential application of activated carbon from maize tassel for the removal of heavy metals in water. Phys Chem Earth Parts A/B/C 50-52:104-110. doi:10.1016/j.pce.2012.06.001

Ould-Idriss A, Stitou M, Cuerda-Correa EM et al (2011) Preparation of activated carbons from olive-tree wood revisited. I. Chemical activation with $\mathrm{H}_{3} \mathrm{PO}_{4}$. Fuel Process Technol 92:261-265. doi:10.1016/j.fuproc.2010.05.011
Perrin A, Celzard A, Albiniak A et al (2004) $\mathrm{NaOH}$ activation of antracites: effect of temperature on pore textures and methane storage ability. Carbon 42:2855-2866

Prakash Kumar BG, Miranda LR, Velan M (2005) Adsorption of Bismark Brown dye on activated carbons prepared from rubberwood sawdust (Hevea brasiliensis) using different activation methods. J Hazard Mater 126:63-70. doi:10.1016/j.jhazmat. 2005.05.043

Schellenberg K, Leuenberger C, Schwarzenbach RP (1984) Sorption of chlorinated phenols by natural sediments and aquifer materials. Environ Sci Technol 18:652-657. doi: 10.1021/ es00127a005

Senturk HB, Ozdes D, Gundogdu A et al (2009) Removal of phenol from aqueous solutions by adsorption onto organomodified Tirebolu bentonite: equilibrium, kinetic and thermodynamic study. J Hazard Mater 172:353-362. doi:10.1016/j.jhazmat.2009. 07.019

Tongpoothorn W, Sriuttha M, Homchan P et al (2011) Preparation of activated carbon derived from Jatropha curcas fruit shell by simple thermo-chemical activation and characterization of their physico-chemical properties. Chem Eng Res Des 89:335-340. doi:10.1016/j.cherd.2010.06.012

Vargas AMM, Cazetta AL, Garcia CA et al (2011) Preparation and characterization of activated carbon from a new raw lignocellulosic material: flamboyant (Delonix regia) pods. J Environ Manage 92:178-184. doi:10.1016/j.jenvman.2010.09.013

Viraraghavan T, Slough K (1999) Sorption of pentachlorophenol on peat-bentonite mixtures. Chemosphere 39:1487-1496. doi:10. 1016/S0045-6535(99)00053-3

Weber WJ, Morris JC (1963) Kinetics of adsorption on carbon from solutions. J Sanit Eng Div Am Soc Civ Eng 89:31-60 